\title{
DROUGHT MANAGEMENT OF COCONUT HOLDINGS
}

\author{
By \\ Dr. D. V. Liyanage ${ }^{1}$
}

\begin{abstract}
Prolonged droughts retard growth of coconut palms and reduce production. Current systems of chemical farming in coconut holdings do not mitigate adverse drought effects on palms. They should be replaced with bio-farming techniques, which will result in improvement of structure, water holding capacity and fertility of the soil, thereby delaying onset of soil moisture stress during dry seasons.

With the drought management practices based on mulching bio-farming, soil nutrients are released gradually so that coconut production is sustained at a high level without much fluctuations through-out the years. Further, that technology is simple and large investments are not necessary, particularly application of the Coconut/Gliricidia model. Cost of production of coconuts is reduced with bio-farming.
\end{abstract}

\section{INTRODUCTION}

Water is of vital importance to the growth of plants. Some plants have the capacity to store water to be used during dry seasons, but a coconut palm is not one of them. Root system is shallow without a tap root that could draw subterranean water. Hence palms depend entirely on water in the upper layers of soil, which could dry up rapidly during dry seasons creating a soil moisture stress.

Coconut growing countries in Asia experience dry seasons each year with varying intensities. Most of the area under coconut cultivation in Sri Lanka is in dry and intermediate climatic zones, 29 and $51 \%$ respectively. National production varied between 1,821 and 3,039 million nuts per year during the last decade depending on rainfall and distribution. These figures demonstrate the necessity to implement drought management practices in coconut holdings.

This paper discusses rainfall requirements for successful cultivation of coconut palms, effect of soil moisture stress on production and management practices that could be adopted to mitigate drought damage.

\section{RAINFALL REQUIREMENTS}

According to Fremond, et $\mathrm{al}^{1}$ coconut palms do not suffer from drought with $1,500 \mathrm{~mm}$ rainfall per year spread uniformly through-out the year. But, if it is less than $130 \mathrm{~mm}$ in any month, a yield depression could occur, unless relieved by a high water table. The most that could be tolerated by palms is three months less than $50 \mathrm{~mm}$ rainfall per month.

Menon and Pandalai ${ }^{2}$ consider coconut palms could grow and bear fruits with a well distributed rainfall of $1,000 \mathrm{~mm}$ per year, but for profitable cultivation 1,000 to $2,250 \mathrm{~mm}$ per year is necessary.

$\mathrm{Ohler}^{3}$ states that ideal rainfall for coconut palms is closer to $2,500 \mathrm{~mm}$ than $1,500 \mathrm{~mm}$ per year, provided other sources of water are not available.

\footnotetext{
${ }^{1}$ Consultant (Research \& Development) Colombo, Sri Lanka.
} 
In the dry zone of Sri Lanka, with a rainfall around 1,000 $\mathrm{mm}$ per year and two severe dry seasons each extending over two months, there are a few coconut holdings located on latosols producing over 8,500 nut ha/yr. The high yields are attributed to good management.

All authors emphasize the necessity for a good distribution of rainfall for coconut cultivation. This is necessary, as coconut palms cannot store water and the root system is shallow depending largely on moisture in the upper layers of soil.

Rainfall requirements of coconut palms are related to a number of factors: (a) soil structure and depth, (b) water holding capacity of soil, (c) height of around water table, (d) rate of evaporation of water from ground surface, (e) rate of transpiration from leaves. However as a general rule the Tall variety of coconut palms (var, typica) requires a rainfall of about $1,500 \mathrm{~mm}$ per year with a uniform distribution, dry season-rainfall less than $50 \mathrm{~mm}$ per month - not exceeding two consecutive months.

\section{DROUGHT DAMAGE ON PALMS}

Abeywickrame et al ${ }^{4}$ have indicated that drought periods slow down/arrest activity of the growing point of stem. Leaf production is reduced and cause early aging and collapse. Palms without a minimum of about twenty leaves lack the vitality to produce nuts. Droughts arrest spikelet formation in the inflorescence bud, resulting in a loss of female flowers. Button and immature nut fall are heavy. Weight of fruit, husk and endosperm is reduced.

When soils dry up for any prolonged period, outer cells in the absorbing region of roots develop thickened walls drought which water cannot enter. Droughts reduce nut formation in other ways. When water courses run dry, rodents and other animals open the husks of immature coconuts to drink water. These nuts drop prematurely. Further, dry conditions increase activity of leaf pests such as Coconut caterpillar and Coconut scale.

All these factors contribute to a considerable reduction in production and loss of palms, if drought conditions are severe. Coconut cultivation in the Puttalam district, Sri Lanka covered about 59,000 ha in 1950. That area was exposed to severe droughts for four consecutive years from 1947 to 1950. In the last year rainfall was only $767 \mathrm{~mm}$, seven months receiving less than $50 \mathrm{~mm}$, per month, five of them being consecutive (rainfall data for other years not available). Then coconut palms suffered severe damage: about 300,000 palms dead and 700,000 adversely affected.

A further example of crop loss due to drought is given below. Data on national coconut production in Sri Lanka are available from 1950 to 1991 (5). Period 1951 to 1965 could be considered quite stable for the coconut industry. Thereafter, there was a progressive decline of the area under coconut cultivation and holdings were neglected due to land reforms. For these and other reasons, only data for years 1951 to 1965 are presented in the analyses. The figures for rainfall are a weighted average computed on a basis of rainfall stations in coconut growing areas. Drought months are defined as those with a rainfall below $50 \mathrm{~mm}(5)$.

$\begin{array}{lllllll}\text { Years without drought: } & \mathbf{1 9 5 1} & \mathbf{1 9 5 4} & \mathbf{1 9 6 1} & \mathbf{1 9 6 3} & \mathbf{1 9 6 4} & \text { Mean } \\ \begin{array}{l}\text { Production (million nuts) } \\ \begin{array}{l}\text { Production following year- } \\ \text { (million of nuts) }\end{array}\end{array} & 2,238 & 2,203 & 2,601 & 2,549 & 2,991 & 2,516 \\ & 2,455 & 2,420 & 2,811 & 2,991 & 2,676 & 2,671\end{array}$


Years with drought:

Production (million nuts)

Production following year-

(million nuts)

195

2,288

1956

1957

1958

1960

Mean

The effect of rainfall on production is generally seen in die following year. When the years, with satisfactory rainfall are considered, national production averaged 2700 million nuts per year, but dropped to 2,300 million when that was unsatisfactory: a loss, of 400 million nuts per year.

"Recovery after a severe drought is a slow process. Normal root absorption does not commence with the onset of first rains. First growing points of roots have to be reactivated. This is followed by root elongation and formation of a new absorbing region. With the resumption of water supply shoot activity begins and new leaves and inflorescences are formed. In extreme cases up to about two years may be necessary for a full recovery after a prolonged drought" ${ }^{4}$.

\section{SOIL MOISTURE CONSERVATION}

Abeywickrame, et a $1^{4}$ have given simple methods to maximize soil moisture conservation:

Mulching around palms by spreading vegetable material, e.g. coconut fronds, husks, lopping of trees and shrubs. Mulching should be carried out regularly so that soil is not exposed. It protects soil from direct solar radiation and wind effects reduce water loss and controls weed growth.

Burying husks in trenches in the proximity of palms. Husks act like a sponge, can absorb and retain water about six times its own weight.

Increase infiltration of water into the soil by terracing, contour drains and/or contour bunds.

Build bunds across folds on the ground of undulating land to form mini tanks. They retain water flowing from, the higher land to be used for at least a part of the dry season. This technique could be used on more clayey and lateric soils. Irrigation of seedlings during dry seasons results in rapid establishment and vigorous growth. A convenient method is pitcher irrigation, where two large earthen ware pots (18 1 capacity) are buried one meter away on either side of seedling. Surface of pot facing away from seedling should be made impervious by an application of tar or other paint to prevent unnecessary water loss. The pitcher should be filled with water and replenished as necessary.

\section{ORGANIC FARMING}

Other synonyms for organic farming are: bio-farming, conservation farming, sustainable agriculture, etc. The general principle in them is to eliminate or reduce use of chemical fertilizers, herbicides and pesticides in Cultivation of crops and replace them with organic material. Some of the nutrients required for plant growth could be derived from vegetable material and animal litter. Pests to be controlled with appropriate parasites.

Researchers have described a number of leguminous plants that provide nitrogen, phosphate, potassium, calcium and magnesium, essential elements for nutrition of coconut palms. Amongst them 
Gliricidia, Leucaena, cover crops, etc are important. Leaves lopping of these tree crops provide all the nitrogen and a part of other nutrient requirements of coconut palms.

According to Liyanage ${ }^{7}$ Gliricidia stands pruning two to four times a year. One hundred plants two to three years old produce about $500 \mathrm{~kg}$ of green lopping with two pruning a year, providing nutrients equivalent to $13 \mathrm{~kg}$ of urea, $4 \mathrm{~kg}$ saphos phosphate, $6 \mathrm{~kg}$ of muriate of potash and $5 \mathrm{~kg}$ dolomite (approx.).

Crop-live stock farming also contributes to organic farming. Animal dung and urine improves fertility and water holding capacity of soil. Integrated pest control with minimal use of insecticides is another aspect of bio-farming. Pests arc controlled with introduced parasites. out that:

Wijewardane and Waidyanatha ${ }^{6}$ in their discussion on conservation farming have pointed

The impact of rain drops of intensive tropical rain storms falling on exposed soils is to break up surface soil aggregates causing surface sealing and compaction. This seals infiltration of rainfall which then runs down the slope resulting in erosion.

The effect of ground cover on run off of rainfall and soil losses on a $10 \%$ slope has, been estimated as (adapted from Lal):

\section{Bare ground}

Soil loss (t/ha)

Run off (\% of rainfall)

\section{Mulched}

Large quantities of organic matter and nutrients are lost through erosion and leaching: nearly two tones of organic matter and $200 \mathrm{~kg}$ of nitrogen are lost from, a hectare of bare land each year on $10 \%$ slope.

Soil temperatures are lower and fluctuations reduced under and vegetation cover: 25 to $30^{\circ} \mathrm{C}$ under mulches as against 40 to $45^{\circ} \mathrm{C}$ on bare soils. High soil temperatures (over $60^{\circ} \mathrm{C}$ ) can adversely affect crop emergence, vigor and yield of plants.

These reports have described methods to reduce run off of water and increase infiltration of rainfall so that the soil could retain water to maximum capacity possible. These principles should be used to develop a system of agriculture that will mitigate effect of drought on coconut production. A feasible approach is to follow the organic farming system already practiced in a number of countries.

\section{DROUGHT MANAGEMENT OF COCONUT HOLDINGS}

Sections 5 and 6 describe a number of techniques that could be adopted to retain moisture in the soil for longer periods during dry seasons. The salient features are to maximize infiltration of rainfall into soil and change soil structure to retain more water. Drought management is application of these principles to delay onset of soil moisture stress, so that plants could survive dry seasons longer. Some of them applicable to coconut holdings arc outlined below.

If coconut holdings are not used for inter-cropping, spread two layers of coconut husks about two to three meters wide-width depends on planting distance-along the space between rows of palms, preferably on contours. Mulch around palms with leaves and crop refuse. If intercropping is to be done, have husk mulch along the rows of coconut palms. Leave sufficient space without mulching for foot paths, picking nuts with bamboo and tractor movements. 
It is important to maintain the mulch continuously. Mulchin. 0 encourages lateral roots to spread near ground surface, which is not a disadvantage as long as the mulch is maintained. Mulches promote infiltration of rainfall, reduce ground temperature and evaporation, check soil erosion and weed growth, resulting in a higher accumulation of water in the soil compared to bare land.

Mulches alone are not sufficient. Practice bio-farming. The simplest method for coconut small-holders is the Coconut/Ghricidia model. Plant along die boundary Gliricidia plants, three for each coconut palm-Prune them two to three times a year - depending on climatic conditions - and use lopping to mulch around coconut palms. Application of $30 \mathrm{~kg}$ per palm/yr provides all the nitro2en and 15 to $20 \%$ of phosphate and potassium requirements ${ }^{7}$.

Gliricidia is grown from seed and cuttings. Sow seed in a pre-nursery and transfer seedlings to poly-bags. Subsequently, plant seedlings and cuttings along the boundary fence in double rows at $60 \mathrm{~cm}$ intervals in equilateral triangular form.

Integrated animal husbandry with coconut cultivation leads to bio-fanning. But, there are difficulties in implementation in the dry zone. Improved cattle needs pasture and fodder. If they are established in coconut holdings, there is competition for moisture and palms will suffer. A feasible approach is to have indigenous cattle and goats feeding in meadows outside coconut holdings during day time and bring them back in the night to use their dung as fertilizer.

The method and system of inter-cropping under coconut palms is also important for drought management. Perennial intercrops like cocoa, coffee, pepper etc compete with palms for water creating a soil moisture stress early in the dry season, which is detrimental to palms. A satisfactory solution to this problem is to grow short term annual crops cereals, pulses, chilly, etc. under palms. They are grown in the wet season and harvested early in dry season. Hence competition for soil moisture between palms and intercrops will not arise.

Perhaps, the Philippine technique ${ }^{8}$ will be useful for intercropping with annual crops. Giant Ipil Ipil (Leucaena) is planted close together in double hedges on contours four meters apart on denuded mountain slopes. The trees are cut back ten times a year and loppings are used to fertilize crops grown between hedges without ploughing: corn, bean, sweet potatoes, pineapple, banana, coffee and fruit trees have been grown successfully. In the case of coconut holdings two rows of Ipil Ipil or Gliricidia could be grown along center of every third or fourth row and loppings used for intercropping or as fertilizer or for mulching palms.

Irrigation with gravity flow or deep wells is ideal to overcome adverse effects of drought on growth of palms and production. That requires large investments which are beyond the resources of small farmers. It is more suitable for the estate Sector.

\section{DISCUSSION}

The beneficial effects of continuous application of bio-farming systems are immense. Some of them are:

Improvement of structure and fertility of soil. A living soil is created teeming with fungi, bacteria and earth worms which help transfer and absorption of nutrients.

Earth worms turn organic waste into nutrients by constant burrowing, mixing and digestion. They neutralize excessively acidic or alkaline soils. They transport minerals and compounds in sub-soil to die surface. Their excreta is said to contain twice the amount of phosphate and eleven times potassium than present in surrounding soil. They keep soil loose giving a better capacity to retain air and water. 
A combination of mulching and bio-farming reduces ground temperature and erosion, improves soil structure and increases infiltration of rainfall, water holding capacity and fertility of soil. The cumulative effect is that onset of soil moisture stress during dry seasons is delayed considerably so that palms could survive droughts. Further, as soil nutrients are released gradually with bio-farming, production is sustained at a satisfactory level through-out the years without wide fluctuations that is associated with droughts.

Bio-farming brings about economic benefits in addition to agronomic advantages. On a basis of current recommendations, to maintain a coconut holding at an economic: level in Sri Lanka, application of chemical fertilizers and various agronomic practices are necessary. Expenditure involved in maintaining a coconut small holding, without considering overhead expenses is:

$\begin{array}{llll}\text { Fertilizer (chemical) } & : & 58 \% \text { of total expenditure } \\ \text { Transport \& application } & : & 08 \% \text { of total expenditure } \\ \text { Picking, collecting \& counting } & : & 08 \% \text { of total expenditure } \\ \text { Pests, diseases \& weeding } & : & 08 \% \text { of total expenditure } \\ \text { Other cultural practices } & : & 12 \% \text { of total expenditure } \\ \text { Miscellaneous } & : & 06 \% \text { of total expenditure }\end{array}$

Data from CDA, Colombo, 1992

Cost of chemical fertilizer is a substantial item of expenditure amounting to more than half of the total expenditure to maintain a coconut smallholding. As bio-farming provides all the nitrogen and a part of phosphate, potassium and magnesium requirements of palms, there is a saving of about $45 \%$ of expenditure on fertilizer.

No doubt, application of chemical fertilizer boosts crops for a short period, but it does not improve the quality of soil. It eliminates earth worms. It does not mitigate drought effects on palms.

Reoanold ${ }^{2}$ after studying organic and conventional farming systems in 16 farms in New Zealand has reported that, "With organic farming soils had significantly greater organic matter content and microbial activity, more earth worms, better soil structure, lower bulk density, easier penetrability and thicker top soil. Further, profitability was similar to those practicing conventional farming".

A modest assumption is that if mulching and bio- farming are carried out in coconut holdings in Sri Lanka, production from existing stands with a density of $130 \mathrm{palms} / \mathrm{ha}$, would be at least $10,000 \mathrm{nut}$ ha/yr. Further, cost of production will be much less than with chemical farming.

\footnotetext{
${ }^{2}$ As reported in Daily News. Colombo in May 1993
} 


\section{REFERENCES}

1. Fremond $\mathrm{Y}$, Ziller R and Nuce de Lamothe. The Coconut Palm. Published by International Potash Institute, Berne (1966)

2. Menon K P V and Pandalai K N. The Coconut Palm. Published by Indian Central Coconut Committee, Ernakulam (1960)

3. Ohler J G. Coconut, Tree of Life. Published by FAO, Rome (1984)

4. Abeywickrame B A, Livanage D V and Wijewardane R. Measures to Minimize Drought Damage in Coconut Plantations. Report submitted to the Minister of Coconut Industries, Colombo (1983).

5. Coconut Statistics. Sri Lanka. Published by the Coconut Development Authority, Colombo (1991).

6. Wijewardane R and Waidyanatha P. Conservation Farming. Published by Department of Agriculture, Sri Lanka and Commonwealth Consultative Group on Agriculture (1 984).

7. Livanage L V K. Gliricidia as a multipurpose tree for coconut plantations. Coconut Bulletin V 1, Coconut Research Institute, Sri Lanka (1988).

8. Watson H L. Innovative technique restores fertility to bold mountain sides. As reported by D C Abdulla in Bulletin Today, 4 December 1985. 